\title{
Karakteristik dan Makna Rekreasi Pengunjung dalam Leisure dan Recreation di Tukad Bindu Kota Denpasar
}

Shofyan Hadi Ramadhan a, 1, I Nyoman Sukma Arida a, 2

${ }^{1}$ shofyanhadi7@gmail.com, ${ }^{2}$ sukma_arida@unud.ac.id

a Program Studi Sarjana Destinasi Pariwisata, Fakultas Pariwisata, Universitas Udayana, Jl. Dr. R. Goris, Denpasar, Bali 80232 Indonesia

\section{Abstract}

Tukad Bindu at first was well-known as the dirty river and contained tons of household waste thrown away by society. Nevertheless, since 2018 it became one of recreation center in Denpasar City. Many activities carried out currently and the more crowded Tukad Bindu becomes, it is necessary to conduct a research which is expected to be able to perceive the characteristic and the meaning of recreation in Tukad Bindu to be a consideration for further development. The research method used is qualitative method with qualitative descriptive data analysis technique. The data resource of this research is from primary and secondary data. Data collection technique is conducted by observation, interview, questionnaire, and documentation. Sample determination is committed by accidental sampling using nonprobability sampling technique. Informant determination is committed by purposive sampling procedure.

The result of this research indicates that progress level of Tukad Bindu is start on the development stage. The characteristics of Tukad Bindu visitors are perceived from socio-demographic characteristic, demographic characteristic, and psychographic characteristic turns out to be very diverse. The meaning of visitors' recreation after having recreation in Tukad Bindy mostly are social meaning. Community should keep supporting activities committed by Tukad Bindu Foundation, particularly the youths there. It is expected that Tukad Bindu Foundation continues to hold regular annual events, such as Pekan Nusantara. Academics should synergize with each other in order to create an integrated recreation area among the fields of fishery, agriculture, and tourism.

\section{Keyword: Characteristics, The Meaning of Recreation, Leisure and Recreation}

\section{PENDAHULUAN}

Pulau Bali merupakan salah satu destinasi utama di Indonesia yang sejak lama sudah dikenal hingga mancanegara. Pulau Bali memiliki beragam daya tarik wisata seperti wisata alam, budaya, maupun buatan yang bisa dikunjungi saat wisatawan memiliki waktu luang. Menurut Badan Pusat Statistik Provinsi Bali jumlah kunjungan wisatawan ke Bali setiap tahunnya mengalami peningkatan, pada tahun 2017 berjumlah 5.697.739 wisatawan mengalami peningkatan 6,54 \% di tahun 2018 menjadi 6.070.473 wisatawan (Badan Pusat Statistik Provinsi Bali, 2019).

Hal ini tidak lepas dari beragam aktivitas rekreasi yang dapat dilakukan di Pulau Bali. Saat ini manusia cenderung sibuk dengan kegiatan ekonomis yang dimotivasi oleh pemenuhan kebutuhan primer, sekunder, dan tersier. Akibat kesibukan mengejar materi manusia memiliki titik kejenuhan dalam melakukan kegiatan di waktu bekerja sehingga membutuhkan adanya rekreasi untuk memulihkan diri saat waktu luang (Suryasih, 2019).

Menurut Tordkildsen kata leisure berasal dari bahasa Prancis yaitu loisir yang berarti waktu luang (free time) (Tordkildsen, 1999). Waktu luang dapat digunakan untuk melakukan berbagai aktivitas karena terlepas dari waktu produktif (bekerja, sekolah, dan lain-lain) dan waktu biologis (mandi, makan, dan lain-lain). Adapun salah satu kegiatan atau aktivitas yang dapat dilakukan dalam waktu luang adalah rekreasi. Rekreasi (recreation) merupakan suatu kegiatan yang dibutuhkan oleh manusia untuk mencapai kepuasan rohani dan jasmani (Krippendorf dalam Suryasih, 2019).

Kota Denpasar merupakan ibukota dari Provinsi Bali yang menjadi pusat ekonomi, pusat pemerintahan, dan pusat pelayanan publik menyebabkan Kota Denpasar menjadi sangat padat. Menurut data Kementerian Dalam Negeri jumlah penduduk di Kota Denpasar pada tahun 2018 mencapai 647.954 jiwa (DKB Kementerian Dalam Negeri, 2018). Hal ini ditambah dengan Kota Denpasar yang juga merupakan daerah tujuan wisata oleh wisatawan domestik maupun mancanegara yang berkunjung ke Bali.

Tukad Bindu pada awalnya dikenal dengan sungai yang kotor dan banyak sampah rumah tangga yang di buang oleh masyarakat. Namun sejak tahun 2018 menjadi salah satu tempat rekreasi di Kota Denpasar. Hal ini dikarenakan pada tahun 2017 dilakukan pembersihan dan pengelolaan yang berlanjut menjadi taman rekreasi yang menyenangkan (Suyatra dalam baliexpress.jawapos.com, 2018).

Pengelolaan Tukad Bindu dikelola oleh Yayasan Tukad Bindu Kesiman yang mulai terbentuk pada tahun 2017. Tukad Bindu saat ini dilengkapi dengan berbagai sarana dan prasarana untuk menunjang leisure and recreation.

Melihat Tukad Bindu yang makin gencar 
mengembangkan diri menjadi tempat rekreasi guna memberikan manfaat kepada pengunjung, maka peneliti merasa perlu untuk dilakukan penelitian tentang karakteristik dan makna rekreasi pengunjung dalam leisure and recreation di Tukad Bindu, Desa Kesiman Petilan, Kota Denpasar. Sehingga dengan dilakukannya penelitian ini dapat diketahui karakteristik dan makna rekreasi yang didapat pengunjung di Tukad Bindu. Untuk menjadi pertimbangan pengembangan selanjutnya.

Dalam penelitian ini digunakan telaah penelitian sebelumnya guna mengetahui persamaan dan perbedaan, serta menghindari adanya plagiasi. Penelitian yang pertama dilakukan oleh Gede Indra Bhaskara dan Nyoman Ega Ismana (2019) dengan judul "Pemanfaatan Krisna Funtastic Land Sebagai Sarana Leisure and Recreation Di Desa Temukus Kabupaten Buleleng". Dalam penelitian ini dibahas tentang identifikasi karakteristik dan motivasi pengunjung Krisna Funtastic Land untuk mengetahui pemanfaatan leisure and recreation yang tepat. Penelitian ini dilakukan dengan analisis deskriptif statistik sehingga mampu menceritakan gambaran mengenai karakteristik dan motivasi pengunjung Krisna Funtastic Land berdasarkan data yang diperoleh.

Penelitian yang kedua dilakukan oleh TienMing Cheng dan Sheng-Hshiung Tsaur (2011) dengan judul "The Relationship Between Serious Leisure Characteristics And Recreation Involvement: A Case Study Of Taiwan's Surfing Activities". Dalam penelitian ini dibahas tentang hubungan karakteristik pengunjung dalam serious leisure dengan recreational involvement pada pengunjung di Southern Taiwan's Kenting Jialeshuei Coast and Northern Taiwan's Ilan Northeast Coast. Penelitian ini dilakukan dengan analisis deskriptif dan Confirmatory Faktor Analisis (CFA).

Penelitian yang ketiga dilakukan oleh Putu Ratna Juwita Sari (2018) dengan judul "Pemberdayaan Masyarakat Lokal Dalam Pengelolaan Wisata Alam Tukad Bindu Di Kota Denpasar". Dalam penelitian ini dibahas tentang peran serta masyarakat dalam pengelolaan wisata alam Tukad Bindu. Penelitian ini dilakukan dengan deskriptif kualitatif menggunakan analisis SWOT.

Penelitian yang keempat dilakukan oleh Alan D. Bright Dan Rob Porter (2001) dengan judul "Wildlife-Related Recreation, Meaning, and Environmental Concern". Dalam penelitian ini dibahas tentang makna rekreasi dan kepedulian lingkungan. Penelitian ini dilakukan dengan analisis faktor

Penelitian yang terakhir dilakukan oleh Nina Ester Parhusipa dan I Nyoman Sukma Arida
(2018) dengan judul "Wisatawan Milenial Di Bali (Karakteristik, Motivasi, Dan Makna Berwisata". Dalam penelitian ini dibahas tentang karakteristik, motivasi, dan makna berwisata dari wisatawan milenial. Penelitian ini dilakukan dengan teknik analisis data kualitatif dan analisis statistik deskriptif.

Konsep yang digunakan untuk menganalisis rumusan masalah dalam penelitian ini yaitu konsep leisure (Torkildsen, 1999), konsep rekreasi (Boniface dan Cooper, 1998), konsep tourist descriptor (Seaton dan Bennet, 1996), konsep makna rekreasi (Suryasih, 2019), dan konsep pengunjung (Baron dalam Theobald, 2005). Teori yang digunakan dalam penelitian ini adalah Teori Tourism Area Life Cycle (TALC) (Butler, 1980).

\section{METODE PENELITIAN}

Tukad Bindu adalah sebuah sungai yang terletak di Desa Kesiman Petilan, Kecamatan Denpasar Timur, Kota Denpasar, Bali. Tukad Bindu ini masih berada di Kota Denpasar. Untuk menuju Tukad Bindu pengunjung harus melewati Jalan Turi dan memasuki Gang Sardula. Karena letaknya yang ada di Kota Denpasar sehingga banyak pengunjung yang memanfaatkannya untuk menghabiskan waktu luang dengan rekreasi. Dalam penelitian ini Tukad Bindu dipilih sebagai lokasi penelitian karena merupakan tempat rekreasi yang sedang berkembang dengan fasilitas dan kegiatan yang beragam.

Dalam penelitian ini untuk membatasi permasalahan maka dipilih dua ruang lingkup penelitian yaitu karakteristik dan makna rekreasi pengunjung Tukad Bindu. Karakteristik pengunjung Tukad Bindu yang dimaksud meliputi karakteristik sosio-demografis, karakteristik geografis, dan karakteristik psikografis. Makna rekreasi pengunjung Tukad Bindu yang dimaksud meliputi makna kesehatan, makna pendidikan, dan makna sosial.

Penelitian menganut paradigma kualitatif meskipun tidak hanya menggunakan metode kualitatif tetapi juga metode kuantitatif (Anom, dkk., 2019). Jenis data dalam penelitian ini adalah data kualitatif (Bungin, 2007:103) dan data kuantitatif (Sugiyono, 2011). Data kualitatif dalam penelitian ini meliputi makna kesehatan, makna pendidikan, makna sosial, gambaran umum dan pengembangan Tukad Bindu. Data kuantitatif dalam peneitian ini meliputi data jumlah kunjungan, karakteristik sosiodemografis, karakteristik geografis, dan karakteristik psikografis.

Sumber data dalam penelitian ini adalah sumber data primer (Sugiyono, 2011) dan sekunder (Moleong, 2005). Data primer dalam penelitian ini meliputi data gambaran umum Tukad Bindu, data pengembangan Tukad Bindu, karakteristik sosio- 
demografis, karakteristik geografis, karakteristik psikografis, makna kesehatan, makna pendidikan, dan makna sosial. Data sekunder berupa data jumlah kunjungan pengunjung Tukad Bindu dan struktur pengelola Tukad Bindu.

Teknik pengumpulan data yang digunakan meliputi wawancara (Bungin, 2007) dengan Ketua Yayasan Tukad Bindu Kesiman dan 5 pengunjung. Menurut Roscoe (1975) dalam menentukan sampel ada beberapa hal yang harus diperhatikan yaitu:

1. Ukuran sampel lebih dari 30 dan kurang dari 500 adalah tepat untuk kebanyakan penelitian

2. Jika sampel dipecah ke dalam subsampel (pria/wanita, junior/senior, dan sebagainya), ukuran sampel minimum 30 untuk tiap kategori

3. Dalam penelitian mutivariate (termasuk analisis regresi berganda), ukuran sampel sebaiknya 10x lebih besar dari jumlah variabel dalam penelitian

4. Untuk penelitian eksperimental sederhana dengan kontrol eskperimen yang ketat, penelitian yang sukses adalah mungkin dengan ukuran sampel kecil antara 10 sampai dengan 20

Mengacu pada point pertama dan mempertimbangkan waktu penelitian, maka sampel dalam penelitian ini berjumlah 35 responden. Adapun kriteria sampel dalam penelitian ini adalah:

1. Pernah mengunjungi Tukad Bindu

2. Melakukan aktivitas leisure and recreation di Tukad Bindu

Kuesioner (Sugiyono, 2011) yang disebar ke 35 responden, pengamatan (Bungin, 2007:118) untuk mengecek validitas makna rekreasi, dan dokumentasi (Bungin, 2007) untuk mendapatkan informasi tambahan tentang jumlah pengunjung Tukad Bindu, gambaran umum Tukad Bindu dan sejarah Tukad Bindu.

Hasil observasi dan wawancara ditunjang oleh hasil kuesioner pertanyaan terbuka kemudian dianalisis menggunakan teknik analisis data kualitatif. Teknik analisis data kualitatif dalam penelitian menggunakan teknik analisis data kualitatif dari Miles dan Huberman (Sugiyono, 2014). Analisis data kualitatif dilakukan pada saat pengumpulan data berlangsung dan pada periode tertentu setelah selesai pengumpulan data dengan tiga tahapan yaitu reduksi data, display data, dan kesimpulan serta verifikasi.

\section{HASIL DAN PEMBAHASAN}

A. Gambaran Umum Tukad Bindu
Tukad Bindu merupakan salah satu tempat rekreasi di sempadan sungai yang bersih di Kota Denpasar. Letak Tukad Bindu secara administratif berada di Desa Kesiman Petilan, Kecamatan Denpasar, Provinsi Bali. Secara geografis Tukad Bindu terletak antara $8^{\circ} 38^{\prime} 37.6^{\prime \prime}$ LS - 115'14'08.9" BT dan 8038'17.9" LS - 115'14'02.1" BT. Untuk menuju Tukad Bindu Pengunjung bisa melewati Jalan Turi dan masuk ke Gaang Serdalu. Tukad Bindu melewati empat banjar yaitu, Banjar Ujung, Banjar Abian Nangka Kaja, Banjar Abian Nangka Kelod, dan Banjar Dukuh. Panjang aliran Tukad Bindu yaitu sekitar 1,5 km yang mengalir dari utara di dekat Banjar Ujung hingga ke selatan di Banjar Dukuh.

Tukad Bindu saat ini di kelola oleh masyarakat sekitar dan dinaungi oleh Yayasan Tukad Bindu Kesiman. Tukad Bindu sendiri terletak di sempadan sungai dengan kondisi alam yang masih asri karena di sempadan sungai banyak terdapat pepohonan. Kondisi air di Tukad Bindu masih bersih karena masyarakat di sekitar sadar akan pentingnya kebersihan sungai sehingga tidak ada masyarakat yang membuang sampah ke sungai. Warna air Tukad Bindu cukup bening tetapi warna air sungai terlihat kecoklatan saat musim hujan dikarenakan terbawanya lumpur bersamaan dengan aliran sungai dari hulu. Aliran air Tukad Bindu pada kondisi cuaca cerah tidak terlalu deras sehingga aman untuk digunakan berenang dan masyarakat biasanya juga menggunakannya untuk mencuci baju, tetapi jika kondisi cuaca sedang hujan maka aliran sungai menjadi deras. Selain itu Tukad Bindu juga memiliki beberapa atraksi wisata seperti:

1. Penangkaran hewan: Tukad Bindu memiliki penangkaran burung, adapun jenisnya adalah merak dan burung merpati.

2. Wahana bermain anak: Tukad Bindu memiliki wahana bermain anak dimana didalamnya terdapat berbagai macam permainan untuk anak, seperti ayunan, perosotan, dan jungkat - jungkit.

3. Alat olahraga: Tukad Bindu memiliki alat olahraga yang dapat digunakan pengunjung untuk berolahraga, adapun alat olahraga seperti sepeda statis, alat sit up, alat pull up, dan lain sebagainya.

4. Spot foto: Tukad Bindu memiliki beberapa spot foto yang sangat menarik, seperti di atas jembatan dan di taman. Spot foto ini akan sangat terlihat indah pada malam hari karena dilengkapi oleh lampu warna-warni.

5. Taman: Tukad Bindu memiliki beberapa taman seperti taman bunga dan taman tanaman obat dan sayur.

6. Kolam ikan lele dan taman yumina: Tukad Bindu memiliki kola mikan lele bioflok yang 
dikembangkan oleh Yayasan Tukad Bindu Kesiman bekerja sama dengan Kementerian Kelautan dan Perikanan. Dimana hasil panennya di jual dan di olah menjadi ragam produk oleh-oleh khas dari Tukad Bindu. Taman yumina terletak bersebelahan dan terintegrasi dengan kolam lele karena untuk penyiramanan tanaman digunakan air limbah dari kolam lele. Taman ini ditanami sayuran cabai yang ditanam di seratus pot. Kolam ikan lele dan taman yumina ini biasanya digunakan pengunjung yang melakukan kegiatan outing class atau studi banding dari lembaga atau sekolah yang sedang mengunjungi Tukad Bindu.

Pengunjung dapat menggunakan mobil maupun motor untuk mengunjungi Tukad Bindu. Waktu yang dibutuhkan dari Bandara I Gusti Ngurah Rai sampai ke Tukad Bindu sekitar 35 menit, dan jika berkunjung dari Kota Denpasar ke Tukad Bindu hanya memerlukan waktu 10 sampai 15 menit. Tukad Bindu menyediakan fasilitas parkir yang lumayan luas yang terletak di bagian utara untuk mobil dan motor dan di bagian selatan hanya untuk motor, karena dibagian selatan untuk masuknya melewati gang yang sempit. Tukad Bindu juga memiliki fasilitas co-working space dangan free wifi yang disediakan dari Google sehingga pengunjung dapat menikmati layanan internet gratis. Selain itu Tukad Bindu juga membuka food court atau warung yang berada di sebelah utara dan selatan dengan harga yang terjangkau. Warung ini juga menjadi sumber penghasilan untuk masyarakat di sekitar sempadan Tukad Bindu. Selain itu terdapat meeting room atau ruang pertemuan yang biasanya digunakan pengelola untuk menyambut tamu serta digunakan sebagai ruang diskusi dengan lembaga atau instansi yang ingin bekerjasama atau studi banding dengan Yayasan Tukad Bindu Kesiman adapun beberapa lembaga atau instansi yang pernah berkunjung ke Tukad Bindu adalah Bank Dunia, Kementerian Luar Negeri Afrika, Raf Entertainment (Raffi Ahmad), dan Baim Wong. Tukad Bindu juga menyediakan panggung di bagian utara sebagai fasilitas untuk masyarakat atau komunitas yang ingin mengembangkan kesenian. Beberapa fasilitas lain seperti toilet yang berjumlah dua, lima gazebo dan dua puluh lima tempat duduk yang dapat digunakan pengunjung.

\section{B. Perkembangan Tukad Bindu}

Tukad Bindu pada awalnya merupakan sungai yang tidak terlalu bersih karena masyarakat belum sadar akan pentingnya sungai bersih. Kondisi ini terjadi hingga tahun 2010 masyarakat dari empat banjar yaitu, Banjar Ujung, Banjar Abian Nangka Kaja, Banjar Abian Nangka Kelod, dan Banjar
Dukuh berkumpul dan melihat kondisi sungai yang tidak bersih sehingga timbul pemikiran dari sekolompok masyarakat yang sering berkumpul di Tukad Bindu untuk membersihkan dan menata Tukad Bindu. Tujuan utama pembersihan dan penataan tersebut bukan untuk aktivitas rekreasi tetapi lebih kepada kenyamanan masyarakat dan menjaga warisan budaya yaitu lingga-yoni dan tempat melukat. Lingga-yoni adalah simbol dari kejantanan dan kesuburan manusia yang berbentuk arca yang banyak ditemukan di bagian utara Tukad Bindu, sedangkan melukat adalah bagian dari pelaksaan upacara Manusa Yadnya, yang memiliki tujuan untuk membersihkan dan menyucikan pribadi tempat melukat berada di bagian utara. Hal ini berkesinambungan dengan program dari Dinas Lingkungan Hidup Kota Denpasar yaitu PROKASIH (Program Kali Bersih) dimana program ini berguna untuk pengendalian pencemaran air sungai dengan tujuan untuk meningkatkan kualitas air sungai agar tetap berfungsi sesuai dengan peruntukannya. Sehingga banyak masyarakat yang ikut serta untuk membantu membersihkan Tukad Bindu.

Proses pengembangan Tukad Bindu awalnya sulit diterima masyarakat sekitar karena kebanyakan masyarakat disana sudah terbiasa membuang sampah rumah tangga ke sungai. Selama satu setangah tahun dari tahun 2010 masyarakat sekitar yang peduli akan kebersihan sungai terus memberikan edukasi kepada masyarakat lainnya secara langsung rumah ke rumah (door to door) dan mengadakan pertemuan atau rapat dengan banjar, desa, dan masyarakat. Hingga pada akhirnya timbul kesadaran masyarakat dengan sendirinya karena ada rasa saling memiliki dan rasa saling menjaga lingkungan Tukad Bindu. Masyarakat mulai membuat resapan untuk limbah rumah tangga sehingga sampah tidak langsung di buang ke sungai yang peralatannya dibantu oleh pengelola yang dananya di dapat dari pinjaman koperasi.

Perkembangan Tukad Bindu semakin terasa saat banyaknya kunjungan dan bantuan salah satunya dari Bank Dunia (World Bank) untuk membangun senderan di sepanjang sempadan sungai. Badan Keswadayaan Masyarakat (BKM) dari kelurahan turut membantu membantu menyelesaikan perataan senderan di bagian atas sungai. Tetapi proses ini juga sulit karena tanah di sempadan sungai masih dimiliki oleh masyarakat. Setelah diadakan negosiasi dan masyarakat mulai melihat keseriusan untuk mengelola Tukad Bindu maka diadakan $\mathrm{MoU}$ antara masyarakat sekitar dan pengelola agar Tukad Bindu digunakan untuk kegiatan sosial.

Setelah penataan tersebut semakin banyak pengunjung yang datang ke Tukad Bindu untuk 
berekreasi menikmati sungai, bersantai, berenang, dan olahraga. Masyarakat mulai berinisiatif untuk berdagang di sempadan sungai dengan lapak sederhana dari meja. Karena ketersediaan tempat masih terbatas maka kegiatan ini dilangsungkan secara bergiliran setiap harinya.

Seiring dengan kegiatan sosial dan kegiatan ekonomi yang ada di Tukad Bindu, masyarakat mulai mengambil langkah bottom up dengan berdialog kepada camat agar membentuk suatu lembaga untuk mengelola Tukad Bindu sehingga dibentuklah komunitas kali bersih. Selanjutnya karena masyarakat menganggap bahwa komunitas tidak kuat dalam segi hukum maka tahun 2017 dibentuklah Yayasan Tukad Bindu. Yayasan Tukad Bindu didirikan oleh Bapak Ida Bagus Made Ary Manik dan Bapak Ida Bagus Putra Suryanta. Dari sanalah pinjaman dari koperasi di bayarkan dengan uang yang diambil $10 \%$ dari hasil penjualan warung yang dikoordinir oleh Yayasan Tukad Bindu. Yayasan Tukad Bindu tidak mengambil keuntungan secara materi (uang) karena yayasan ini adalah organisasi yang bersifat non-profit. Adapun susunan Yayasan Tukad Bindu dapat dilihat di tabel berikut.

Pada tahun 2017 diselenggarakan penilaian untuk kali bersih tingkat nasional Tukad Bindu terpilih karena memiliki potensi dan didaftarkan oleh Badan Wilayah Sungai (BWS) yang merupakan badan di bawah Dinas Pekerjaan Umum. Dalam penilaian tersebut Tukad Bindu termasuk kedalam lima besar terbaik dari seluruh Indonesia, sehingga dari sanalah Tukad Bindu semakin terkenal di kancah nasional sebagai sungai yang masih alami di Kota Denpasar. Walikota Denpasar juga memberikan dukungan dengan mengadakan kegiatan atau acara di Tukad Bindu dan menggerakkan serta menghimbau seluruh Organisasi Perangkat Daerah (OPD) untuk mengadakan kegiatan di Tukad Bindu.

Salah satu acara yang diselenggarakan di Tukad Bindu adalah Pekan Nusantara. Pekan Nusantara adalah acara yang dilaksanakan oleh Generasi Pesona Indonesia (Genpi) yang bekerjasama dengan Yayasan Tukad Bindu. Dalam acara ini dijual berbagai jenis makanan lokal yang dijual oleh masyarakat sekitar Tukad Bindu seperti sate kakul, sate jamur, sate kelinci, tipat cantok, es daluman, dan bubur bali. Pengunjung Pekan Nusantara juga dapat menikmati beragam hiburan seperti permainan tradisional, musik akustik, dan pertunjukan seni. Selain itu hal unik dari Pekan Nusantara adalah pengunjung yang akan membeli makanan atau minuman berbelanja menggunakan uang kepeng yang ditukar di booth yang sudah disediakan.

Saat ini Tukad Bindu banyak dikunjungi oleh pengunjung umumnya dari masyarakat Bali khususnya Kota Denpasar. Biasanya pengunjung secara pribadi mengunjungi Tukad Bindu. Meskipun begitu banyak juga kunjungan dari lembaga atau sekolah di Bali untuk melakukan kegiatan outbond maupun kunjungan belajar.

Dari penjelasan diatas dapat diketahui bahwa Tukad Bindu mulai memasuki tahapan pengembangan (development), namun belum sepenuhnya berada di tahapan tersebut. Ciri-ciri dalam TALC masih setengah dari semua ciri yang ada pada tahap pengembangan, seperti belum adanya investor asing karena Tukad Bindu dikelola oleh masyarakat dan tidak adanya tenaga kerja asing maupun barang impor untuk wisatawan.

\section{Karakteristik Sosio-demografis Pengunjung Tukad Bindu}

Karakter sosio-demografis dalam penelitian ini digunakan untuk melihat dan mengetahui usia, jenis kelamin, dan pekerjaan pengunjung Tukad Bindu. Adapun hasil dari kuesioner yang telah disebar dapat dilihat dalam tabel dibawah ini.

\section{Tabel 1. Karakteristik Usia Pengunjung Tukad Bindu}

\begin{tabular}{|c|c|c|c|}
\hline No & Usia & $\begin{array}{c}\text { Jumlah } \\
\text { (sampel) }\end{array}$ & Presentase (\%) \\
\hline 1. & $7-21$ & 23 & 66 \\
\hline 2. & $22-36$ & 12 & 34 \\
\hline & Total & 35 & 100 \\
\hline
\end{tabular}

Sumber: Hasil Penelitian, 2020

Berdasarkan tabel 1. dapat dilihat bahwa umur pengunjung yang berkunjung ke Tukad Bindu didominasi oleh usia 7 - 21 tahun yaitu sebanyak 66\%. Hal tersebut dikarenakan usia $7-21$ tahun merupakan generasi z yang lebih banyak memiliki waktu luang. Sedangkan pada usia $22-36$ tahun terdapat $34 \%$ dimana pada usia tersebut merupakan usia produktif manusia, sehingga waktu luang yang dimiliki juga terbatas.

Tabel 2. Karakteristik Jenis Kelamin Pengunjung Tukad Bindu

\begin{tabular}{|c|c|c|c|}
\hline No & Jenis Kelamin & $\begin{array}{c}\text { Jumlah } \\
\text { (sampel) }\end{array}$ & $\begin{array}{c}\text { Presentase } \\
\text { (\%) }\end{array}$ \\
\hline 1. & Laki-laki & 16 & 46 \\
\hline 2. & Perempuan & 19 & 54 \\
\hline & Total & 35 & 100 \\
\hline
\end{tabular}

Sumber: Hasil Penelitian, 2020

Berdasarkan tabel 2. dapat diketahui bahwa pengunjung Tukad Bindu mayoritas adalah perempuan dengan presentase $54 \%$. Meski begitu angka presentase antara laki-laki dan perempuan tidak terpaut jauh yaitu hanya $8 \%$. Hal ini karena Tukad Bindu merupakan tempat rekreasi yang 
tidak terikdat dengan jenis kelamin sehingga lakilaki maupun perempuan dapat melakukan rekreasi di Tukad Bindu.

\section{Tabel 3. Karakteristik Pekerjaan Pengunjung Tukad Bindu}

\begin{tabular}{|l|c|c|c|}
\hline No & Fasilitas & $\begin{array}{c}\text { Jumlah } \\
\text { (Sampel) }\end{array}$ & $\begin{array}{c}\text { Presentase } \\
\text { (\%) }\end{array}$ \\
\hline 1. & Gazebo & 24 & 23 \\
\hline 2. & Wifi & 23 & 22 \\
\hline 3. & Warung & 17 & 16 \\
\hline 4. & Spot Foto & 15 & 14 \\
\hline 5. & Toilet & 15 & 14 \\
\hline 6. & $\begin{array}{c}\text { Sempadan } \\
\text { Sungai }\end{array}$ & 9 & 8 \\
\hline 7. & Alat Olahraga & 3 & 3 \\
\hline & & Total & $\mathbf{1 0 0}$ \\
\hline
\end{tabular}

Sumber: Hasil Penelitian, 2020

Berdasarkan tabel 3. diketahui pekerjaan dari pengunjung Tukad Bindu yang paling banyak adalah pelajar atau mahasiswa sebesar 77\% yang selanjutnya disusul oleh wiraswasta dengan 14\% dan karyawan 9\%. Hal ini dipengaruhi oleh dominasi pengunjung generasi $\mathrm{z}$ dimana saat ini masih dalam usia sekolah. Selain itu Tukad Bindu telah menjadi tempat belajar kelompok atau mengerjakan tugas oleh siswa ataupun mahasiswa.

\section{Karakteristik Geografis Pengunjung Tukad Bindu}

Karakteristik geografis dalam penelitian ini digunakan untuk melihat daerah asal pengunjung Tukad Bindu. Adapun hasil dari kuesioner yang telah disebar dapat dilihat dalam tabel dibawah ini.

Tabel 4. Karakteristik Asal Pengunjung Tukad Bindu

\begin{tabular}{|c|c|c|c|}
\hline No & $\begin{array}{c}\text { Tempat } \\
\text { Tinggal }\end{array}$ & $\begin{array}{c}\text { Jumlah } \\
\text { (sampel) }\end{array}$ & $\begin{array}{c}\text { Presentase } \\
\text { (\%) }\end{array}$ \\
\hline 1. & Denpasar & 25 & 71 \\
\hline 2. & Badung & 7 & 20 \\
\hline 3. & Gianyar & 2 & 6 \\
\hline 4. & Tabanan & 1 & 3 \\
\hline & Total & $\mathbf{3 5}$ & $\mathbf{1 0 0}$ \\
\hline
\end{tabular}

Sumber: Hasil Penelitian, 2020

Berdasarkan tabel 4. dapat diketahui bahwa pengunjung Tukad Bindu dominan bertempat tinggal di Denpasar dengan presentase 71\%. Hal ini dikarenakan pengunjung Tukad Bindu umumnya adalah masyarakat Kota Denpasar selain itu Tukad Bindu terletak di Kota Denpasar sehingga pengunjung memilih tempat rekreasi yang dekat dengan tempat tinggalnya. Dari hal ini dapat diketahui bahwa rekreasi di Tukad Bindu termasuk daily leisure dan daily trip, karena dikunjungi oleh pengunjung lokal maupun regional.

\section{Karakteristik Psikografis Pengunjung Tukad Bindu}

Karakteristik psikografis dalam penelitian ini digunakan untuk melihat fasilitas yang digunakan, aktivitas yang dilakukan, lama waktu berkunjung, dan uang yang dikeluarkan pengunjung Tukad Bindu. Adapun hasil dari kuesioner yang telah disebar dapat dilihat dalam tabel dibawah ini.

\section{Tabel 5. Karakteristik Fasilitas yang Digunakan} Pengunjung Tukad Bindu

\begin{tabular}{|c|c|c|c|}
\hline No & Pekerjaan & $\begin{array}{c}\text { Jumlah } \\
\text { (sampel) }\end{array}$ & $\begin{array}{c}\text { Presentase } \\
\text { (\%) }\end{array}$ \\
\hline 1. & Pelajar/Mahasiswa & 27 & 77 \\
\hline 2. & Wiraswasta & 5 & 14 \\
\hline 3. & Karyawan & 3 & 9 \\
\hline & Total & $\mathbf{3 5}$ & $\mathbf{1 0 0}$ \\
\hline
\end{tabular}

Sumber: Hasil Penelitian, 2020

Berdasarkan tabel 5. diketahui bahwa fasilitas yang paling sering digunakan oleh pengunjung adalah gazebo dengan presentase $23 \%$ yang disusul oleh wi-fi dengan presentase $22 \%$. Hal ini dipengaruhi oleh pengunjung yang umumnya menggunakan gazebo untuk duduk beristirahat sembari menikmati Tukad Bindu. Selain itu wi-fi juga dominan digunakan pengunjung karena gratis dan dimanfaatkan oleh pelajar atau mahasiswa untuk mengerjakan tugas.

Tabel 6. Karakteristik Aktivitas Pengunjung Tukad Bindu

\begin{tabular}{|l|l|c|c|}
\hline No & \multicolumn{1}{|c|}{ Aktivitas } & $\begin{array}{c}\text { Jumlah } \\
\text { (Sampel) }\end{array}$ & $\begin{array}{c}\text { Presentase } \\
\text { (\%) }\end{array}$ \\
\hline 1. & Bersantai & 27 & 37 \\
\hline 2. & Berfoto & 20 & 27 \\
\hline 3. & $\begin{array}{l}\text { Mengerjakan } \\
\text { Tugas }\end{array}$ & 9 & 12 \\
\hline 4. & Memancing & 7 & 9 \\
\hline 5. & Bermain Game & 6 & 8 \\
\hline 6. & Olahraga & 5 & 7 \\
\hline & & Total & $\mathbf{1 0 0}$ \\
\hline
\end{tabular}

Sumber: Hasil Penelitian, 2020

Berdasarkan tabel 6. pengunjung Tukad Bindu $37 \%$ memilih aktivitas bersantai dan diikuti oleh aktivitas berfoto dengan 27\%. Hal ini dikarenakan pengunjung Tukad Bindu dapat menikmati 
pemandangan sungai sembari bersantai guna melepaskan rasa stress akan kehidupan sehari-hari. Selain itu aktivitas berfoto umumnya dilakukan oleh generasi $\mathrm{z}$ yang dimana generasi ini cenderung memprioritaskan popularitas di media sosial sehingga mereka berfoto dan menggunggahnya pada media sosial.

\section{Tabel 7. Karakteristik Lama Waktu Kunjung Pengunjung Tukad Bindu}

Berdasarkan tabel 7. pengunjung biasanya menghabiskan waktu luangnya di Tukad Bindu

\begin{tabular}{|c|l|c|c|}
\hline No & $\begin{array}{c}\text { Makna } \\
\text { Rekreasi }\end{array}$ & $\begin{array}{c}\text { Jumlah } \\
\text { (Sampel) }\end{array}$ & $\begin{array}{c}\text { Presentase } \\
\text { (\%) }\end{array}$ \\
\hline 1. & Makna Sosial & 22 & 63 \\
\hline 2. & $\begin{array}{l}\text { Makna } \\
\text { Kesehatan }\end{array}$ & 8 & 23 \\
\hline 3, & $\begin{array}{l}\text { Makna } \\
\text { Pendidikan }\end{array}$ & 5 & 14 \\
\hline & Total & $\mathbf{3 5}$ & $\mathbf{1 0 0}$ \\
\hline
\end{tabular}

yaitu 1 - 3 jam untuk sekali berkunjung dengan presentase $83 \%$. Hal ini dikarenakan umumnya pengunjung disana hanya memiliki waktu luang 1 3 jam untuk berekreasi di Tukad Bindu, selain itu mayoritas pengunjung berasal dari Kota Denpasar sehingga tidak lama waktu berkunjungnya karena pengunjung dapat kembali lagi ke Tukad Bindu dalam jangka waktu yang pendek yaitu dalam hitungan minggu atau bulan.

Tabel 8. Karakteristik Uang yang Dikeluarkan Pengunjung Tukad Bindu

\begin{tabular}{|c|c|r|r|}
\hline No & $\begin{array}{c}\text { Uang yang } \\
\text { Dikerluarkan } \\
\text { (Rupiah) }\end{array}$ & $\begin{array}{c}\text { Jumlah } \\
\text { (Sampel) }\end{array}$ & $\begin{array}{c}\text { Presentase } \\
\text { (\%) }\end{array}$ \\
\hline 1. & $0-15.000$ & 14 & 40 \\
\hline 2. & $16.000-25.000$ & 12 & 34 \\
\hline 3, & $>26000$ & 9 & 26 \\
\hline & Total & $\mathbf{3 5}$ & $\mathbf{1 0 0}$ \\
\hline
\end{tabular}

Berdasarkan tabel 8 diatas dapat diketahui bahwa uang yang dikeluarkan pengunjung di Tukad Bindu berkisar antara Rp. 0 - Rp. 15.000,00 dengan presentase $40 \%$. Hal ini dikarenakan harga makanan dan minuman disana terjangkau. Harga makanan antara Rp. 7000.00 sampai Rp.10.000,00 sedangkan untuk minuman mulai dari Rp. 2000,00 sampai Rp. $10.000,00$.

\section{E. Makna Rekreasi Pengunjung Tukad Bindu}

Pengunjung pada umumnya mengunjungi Tukad Bindu karena penasaran dengan sungai yang masih bersih. Selain itu tempatnya yang nyaman untuk menghabiskan waktu luang juga merupakan alasan Tukad Bindu banyak dikunjungi. Setelah mengunjungi suatu tempat untuk berekreasi pengunjung memiliki makna rekreasinya masingmasing. Dalam penelitian ini makna rekreasi yang dilihat adalah makna kesehatan, makna pendidikan, dan makna sosial. Adapun makna rekreasi yang didapat pengunjung dari 35 responden adalah sebagai berikut.

\section{Tabel 9. Makna Rekreasi Pengunjung} Tukad Bindu

Dari ketiga makna rekreasi di atas makna sosial

\begin{tabular}{|c|c|c|c|}
\hline No & $\begin{array}{c}\text { Waktu } \\
\text { (Jam) }\end{array}$ & $\begin{array}{c}\text { Jumlah } \\
\text { (Sampel) }\end{array}$ & $\begin{array}{c}\text { Presentase } \\
\text { (\%) }\end{array}$ \\
\hline 1. & $1-3$ & 29 & 83 \\
\hline 2. & $4-5$ & 6 & 17 \\
\hline & Total & $\mathbf{3 5}$ & $\mathbf{1 0 0}$ \\
\hline
\end{tabular}

menjadi paling banyak dengan presentase $63 \%$ disusul makna kesehatan dengan presentase 23\% dan makna pendidikan menjadi yang paling sedikit dengan presentase $14 \%$.

\section{Makna Sosial}

Makna sosial dipilih pengunjung Tukad Bindu dipengaruhi oleh aktivitas rekreasi yang dilakukan pengunjung umumnya tidak dilakukan sendiri melainkan bersama dengan teman atau keluarga. Dari pengalaman yang dirasakan pengunjung bersantai dengan teman atau keluarga sembari melakukan perbincangan. Sehingga dari hal tersebut menghasilkan interaksi sosial antara pengunjung dengan teman atau keluarga yang diajak ke Tukad Bindu.

Tukad Bindu memiliki food court atau warung yang terletak di bagian utara dan selatan. Meskipun warung merupakan tempat bertemunya penjual dan pembeli yaitu kegiatan ekonomi, tetapi ada komunikasi yang terjalin dan menghasilkan interaksi sosial. Interaksi sosial ini terjadi antara pengunjung dan pedagang warung yang ada di Tukad Bindu. Interaksi sosial ini biasanya terjadi saat pengunjung membeli makanan atau minuman di warung, yaitu di selang kegiatan ekonomi yang pengunjung dan pedagang lakukan. Contohnya saat memesan atau membayar makanan maupun minuman pedagang biasanya menanyakan asal atau tempat tinggal pengunjung. Selain itu pedagang di Tukad Bindu sudah memiliki sikap hospitaliti yang cukup baik hal ini karena dalam rapat maupun pertemuan dengan Yayasan Tukad Bindu biasanya juga ada pemberian materi tentang hospitaliti kepada pengunjung.

Nongkrong yaitu berkumpulnya anak muda di kafe-kafe atau tempat berkumpul lainnya. Tukad Bindu menjadi alternatif tempat nongkrong anak muda untuk kalangan menengah ke bawah. Hal ini karena harga makanan dan minuman yang terjangkau serta adanya jaringan wi-fi yang merupakan fasilitas utama dalam aktivitas 
nongkrong. Ketika sekolompok anak muda sedang nongkrong mereka pasti melakukan pembicaraan yang mengarah pada interaksi sosial. Sehingga dari sanalah makna sosial dikalangan anak muda yang berkunjung ke Tukad Bindu terbentuk.

Pengunjung yang tidak saling mengenal juga dapat berkenalan saat melakukan aktivitas rekreasi. Seperti saat berolahraga terjadi pertemuan antara pengunjung satu dengan lain yang tidak saling kenal kemudian salah satu pengunjung menyapa dan berkenalan. Sehingga terjadi interaksi sosial yang biasanya dari perkenalan singkat tersebut terjalin pembicaraan antar pengunjung tersebut.

\section{Makna Kesehatan}

Manusia melakukan rekreasi sebagai upaya melepaskan masalah yang ada pada dirinya yaitu kewajiban maupun tanggungjawab sehari-hari. Hal ini karena manusia pada umumnya tidak suka dengan kondisi dalam tekanan (pressure). Tekanan (pressure) jika dilakukan terus menerus maka akan merusak kesehatan manusia secara fisik, mental, maupun moral. Oleh karena itu Tukad Bindu sebagai tempat rekreasi juga memfasilitasi pengunjung untuk berolahraga dengan adanya alat olahraga. Pengunjung Tukad Bindu yang memilih makna rekreasi didapat setelah menghabiskan waktu luang dengan melakukan olahraga.

Berlari atau jogging merupakan salah satu olahraga yang bisa dilakukan di Tukad Bindu. Pengunjung dapat berlari jogging di sempadan sungai yang telah disediakan lintasan untuk berlari (jogging track). Tetapi pengunjung harus berhatihati karena lintasan tersebut juga digunakan pengunjung lain sebagai jalan setapak. Panjang jogging track yang ada di Tukad Bindu kurang lebih 1,5 kilometer dengan lebar 2 meter. Tukad Bindu memiliki fasilitas berupa alat olahraga yang terletak di bagian selatan. Alat olahraga yang dimaksud seperti sepeda statis, alat pull up, alat sit up, dan lain sebagainya. Pengunjung biasanya menggunakan alat olahraga ini setelah berlari atau jogging di Tukad Bindu.

Pengunjung Tukad Bindu yang memilih makna kesehatan juga dipengaruhi karena Tukad Bindu dapat dijadikan sebagai tempat untuk memancing. Pengunjung biasanya memancing di bagian utara sungai yang tidak terlalu ramai oleh pengunjung. Kegiatan memancing ini dapat meningkatkan kesabaran sehingga mampu memperbaiki mental pengunjung yang sehari-harinya mendapatkan tekanan (pressure).

Kesehatan tidak hanya terkait dengan fisik tetapi kesehatan moral dan pikiran juga dapat menjadi makna yang didapat ketika melakukan rekreasi. Kesehatan moral bisa didapatkan oleh pengunjung saat menghilangkan penat dengan bersantai. Dengan bersantai dan menikmati pemandangan alam dan suara air mengalir membuat pengunjung mendapat ketenangan. Ketenangan inilah yang menyebabkan pengunjung akan lebih bersemangat lagi untuk menjalani waktu produktifnya. Sehingga dapat tercegah dari tindakan-tindakan yang tidak bermoral dalam hidup. 3. Makna Pendidikan

Ketika melakukan rekreasi di Tukad Bindu pengunjung bisa mendapatkan makna pendidikan. Makna pendidikan diperoleh setelah melakukan kegiatan yang dapat meningkatkan pengetahuan, meningkatkan keterampilan, dan perubahan sikap. Untuk mendapatkan pengetahuan dibutuhkan rasa ingin tahu, biasanya rasa ingin tahu timbul sebelum pengunjung mengunjungi Tukad Bindu yang diawali dengan mencari informasi tentang lokasi rekreasi dan apa saja yang ada disana. Saat ini pengunjung dapat mencari informasi tentang Tukad Bindu melalui media sosial yaitu instagram dengan tagar \#tukadbindu atau langsung melihat di akun instagram @yayasantukadbindukeseman. Selain itu pengunjung juga dapat mencari informasi melalui artikel di internet yang menulis tentang Tukad Bindu.

Saat berada di Tukad Bindu pengetahuan didapat dari aktivitas mengerjakan tugas. Dalam hal ini mengerjakan tugas juga merupakan kegiatan rekreasi dikarenakan ketika tugas sekolah atau kuliah selesai maka menimbulkan rasa bahagia. Tukad Bindu memiliki fasilitas wi-fi dan co-working space yang terletak di bagian utara dan selatan sungai. Wi-fi di Tukad Bindu adalah hasil bantuan dari Google untuk mendukung fasilitas di Tukad Bindu. Penggunaan wi-fi gratis dengan waktu pemakaian 40 menit. Tetapi pengunjung tidak perlu khawatir karena jika waktu tersebut habis pengunjung dapat mengaksesnya kembali dengan cara login kembali. Pengunjung yang biasanya mengerjakan tugas di Tukad Bindu merupakan anak muda yang ada dalam usia sekolah atau kuliah.

Pengunjung yang melakukan outing class biasanya juga mendapatkan makna pendidikan ketika selesai kegiatan tersebut. Dalam outing class yang biasanya digelar oleh siswa sekolah dilakukan pemberian materi tentang lingkungan hidup. Dimana didalamnya yaitu tentang pentingnya menjaga lingkungan dan menjaga ekosistem sungai. Dari kegiatan outing class inilah pengunjung mendapat pengetahuan baru tentang lingkungan.

Selain itu di Tukad Bindu juga sering diadakan studi banding dari lembaga atau instansi dalam bidang perikanan dan sumber daya air. Dalam studi banding tersebut dilakukan pelatihan dengan menjelaskan dan mempraktekkan bagaimana sistem ternak lele dengan cara bioflok yaitu sistem pembibitan dengan mengolah kandungan probiotik yag berupa gumpalan bakteri baik yang berasal dari organisme hidup. Sistem ternak lele bioflok ini juga terintegrasi dengan penanaman tanaman Yumina 
(Sayur Mina) yang ditanam dalam serratus pot yang saat ini ditanami cabai keriting. Dimana sistem penanaman dengan Yumina ini menggunakan limbah air kolam lele sebagai penyiraman kepada tanaman. Maka dari kegiatan studi banding tersebut pengunjung mendapat keterampilan yang baru.

Pengetahuan dan keterampilan yang didapat dari rekreasi akan membawa perubahan terhadap sikap dari pengunjung. Karena semakin bertambah pengetahuan dan keterampilan yang didapat maka pengunjung akan mengalami perubahan positif dari segi sikap. Oleh karena itu sikap pengunjung di Tukad Bindu yang telah mendapatkan makna pendidikan akan semakin baik karena dalam melakukan rekreasi pengunjung mengembangkan hal akademik melalui mengerjakan tugas, menjaga lingkungan melalui outing class, serta keterampilan dalam ternak lele bioflok dan penanaman tanaman yumina melalui pelatihan

\section{KESIMPULAN}

Karakteristik pengunjung Tukad Bindu dilihat dari karakteristik sosio-demografis, karakteristik demografis, dan karakteristik psikografis ternyata sangat beragam. Karakteristik sosio-demografis diketahui bahwa pengunjung Tukad Bindu didominasi oleh usia muda yaitu $7-21$ tahun sebesar 66\%. Yang kebanyaakan merupakan pelajar atau mahasiswa yang $54 \%$ adalah perempuan. Karakteristik geografis pengunjung Tukad Bindu sebanyak 71\% bertempat tinggal di Kota Denpasar, karena Tukad Bindu juga terletak di Kota Denpasar. Dari karakteristik psikografis ada dua fasilitas yang paling sering digunakan oleh pengunjung yaitu gazebo dan wi-fi masing-masing sebesar $23 \%$ dan $22 \%$. Yang dimana dipengaruhi oleh aktifitas yang paing sering dilakukan pengunjung yaitu bersantai dan berfoto dengan presentase masing-masing sebesar $37 \%$ dan $27 \%$. Lama waktu kunjungan pengunjung Tukad Bindu sebagian besar adalah 1 3 jam dengan uang yang dikeluarkan Rp.0 - Rp. $15.000,00$.

Makna rekreasi pengunjung setelah melakukan rekreasi di Tukad Bindu yang paling banyak adalah makna sosial dengan presentase sebesar 63\%. Alasan dipilihnya makna sosial oleh pengunjung karena terjadi interaksi sosial disana. Interaksi sosial di Tukad Bindu terjadi ketika melakukan rekreasi bersama teman atau keluarga sehingga dari sana pasti timbul perbincangan. Selain itu saat memesan atau ketika membayar makanan di warung pedagang disana kebanyakan akan bertanya tempat tinggal atau asal pengunjung. Nongkrong menjadi pemicu terjadinya komunikasi antar teman biasanya terjadi di kalangan anak muda yang berkunjung ke Tukad Bindu. Perkenalan antara pengunjung yang tidak saling kenal juga dapat menimbulkan komunikasi yang termasuk dalam interaksi sosial. Pengunjung mendapat makna kesehatan karena melakukan rekreasi dengan cara berolahraga. Adapun olahraga yang bisa dilakukan di Tukad Bindu adalah berlari (jogging) dan memancing. Hal ini memicu kesehatan fisik, mental, dan moral pengunjung semakin membaik. Pengunjung mendapat makna pendidikan setelah melakukan kegiatan rekreasi dengan meningkatkan pengetahuan, meningkatkan keterampilan, dan perubahan sikap. Pengunjung meningkatkan pengetahuan dengan mencari lokasi dan informasi tentang Tukad Bindu di instagram maupun internet. Pengunjung yang mengerjakan tugas sekolah maupun kuliah mendapat pengetahuan secara akademis menggunakan fasilitas co-working space dan wi-fi. Lembaga atau instansi yang berkunjung ke Tukad Bindu dengan mengadakan outing class ataupun studi banding juga mendapat keterampilan baru tentang lingkungan hidup dan ternak lele bioflok. Pengetahuan dan keterampilan yang didapat dari rekreasi akan membawa perubahan terhadap sikap dari pengunjung. Karena semakin bertambah pengetahuan dan keterampilan yang didapat maka pengunjung akan mengalami perubahan positif dari segi sikap.

\section{DAFTAR PUSTAKA}

Anom, M.Par., Dr. Drs. I Putu dan Mahagangga, S.Sos., M.Si, I Gusti Agung Oka. 2019. Handbook Ilmu Pariwisata Karakter dan Prospek. Jakarta: Prenada Media (Divisi Kencana)

Badan Pusat Statistik Provinsi Bali. 2019. Jumlah Kunjungan Wisatawan. Badan Pusat Statistik Provinsi Bali: Denpasar

Bhaskara, Gde Indra dan Nyoman Ega Ismana. 2019. Pemanfaatan Krisna Funtastic Land Sebagai Sarana Leisure And Recreation Di Desa Temukus Kabupaten Buleleng. Jurnal Destinasi Pariwisata, [S.l.], v. 7, n. 1, p. 91-96, july 2019. ISSN 2548-8937.

Boniface, B. G. dan Cooper, C. P. 1998. The Geography of Travel \& Tourism. Oxford: Heinemann.

Bright, Alan D. Dan Rob Porter. 2001. WildlifeRelated Recreation, Meaning, and Environmental Concern. Human Dimensions of Wildlife, 6:259-276, 2001.

Bungin, Burhan. 2007. Penelitian Kualitatif. Jakarta: Kencana

Butler, R. W. 1980. The concept of a tourist area cycle of evolution: implications for management of resources. The Canadian Geographer/Le Géographe canadien, 24(1), 5-12.

Cheng, Tien-Ming dan Sheng-Hshiung Tsaur. 2011. The Relationship Between Serious Leisure Characteristics And Recreation Involvement: A Case Study Of Taiwan's Surfing Activities. Leisure Studies, 31:1, 5368. 
DKB Kementerian Dalam Negeri. 2018. Jumlah

Penduduk di Kota Denpasar. DKB Kementerian Dalam Negeri: Denpasar.

Moleong, Lexy J. 2005. Metodologi Penelitian Kualitatif. Bandung: Remaja. Rosdakarya.

Parhusip, Nina Ester dan I Nyoman Sukma Arida. 2019. Wisatawan Milenial Di Bali (Karakteristik, Motivasi, Dan Makna Berwisata). Jurnal Destinasi Pariwisata, [S.l.], v. 6, n. 2, p. 299 - 303, jan. 2019. ISSN 25488937

Roscoe, J. T. 1975. Fundamental research statistics for the behavioural sciences. (2nd ed.). New York: Holt Rinehart \& Winston.

Sari, Putu Ratna Juwita. 2018, Pemberdayaan Masyarakat Lokal Dalam Pengelolaan Wisata Alam Tukad Bindu Di Kota Denpasar. Jurnal Ilmiah Dinamika Sosial Vol 2, No 2.

Seaton, A.V dan Bennet M. 1996. The Marketing Tourism products: Concepts, Issues and Cases. International Thomson Business Press: London.

Sugiyono. 2009. Metode Penelitian Kuantitatif, Kualitatif dan R\&D. Bandung: Alfabeta.

Sugiyono. 2014. Metode Penelitian Pendidikan Pendekatan Kuantitatif, Kualitatif dan R\&D. Bandung: Alfabeta.

Sugiyono. 2015. Metode Penelitian: Pendekatan Kuantitatif, Kualitatif, dan $R \& D$. Bandung: Alfabeta.

Suryasih, Ida Ayu. 2019. Buku Ajar Leisure \& Recreation. UWAIS Inspirasi Indonesia: Ponorogo.

Suyatra, I Putu. 2018. Taman Rekreasi Tukad Bindu, Destinasi Alternatif Nyaman untuk Keluarga. (Online), (baliexpress.jawapos.com, diakses 20 Februari 2020).

Theobald, William. 2005. Global Tourism: The Next Decade, New York: Free Press

Torkildsen, George. 1999. Leisure and Recreation Management : Fourth Edition. London. 